\title{
新たな内シャント血流の評価方法の考案とその臨床的意義
}

\author{
脇 坂 佳 成 ${ }^{1}$ 三 浦 徳 宣 $^{2}$ \\ 放射線第一病院循環器科 \\ 2 愛媛大学医学部附属病院泌尿器科
}

キーワード：内シャント血流量，再狭窄，上腕動脈血流，経皮経管的血管形成術，血液透析血流量 〈要旨〉

上腕動脈の超音波検査による抵抗係数（RI）と上腕動脈血流量（FV）と体血圧から導いた内シャント推定血流量 （eSF）を考案し，その指標を内シャント血流係数（SFI）とする．過去 3 年間に 2 回以上経皮経管的血管形成術 （VAIVT）を受けた 79 症例で評価した。特異度 $90 \%$ の条件でVAIVT 前後の SFI の血流低下に対する感度は, RI や $\mathrm{FV}$ よりも勝っていた. その症例の中で脱血穿刺部位の解剖学的状況から脱血流量（Qb）とシャント血流量が近似 すると考える 47 回の VAIVT 直前状態において SFI と近日の体血圧から算出した eSF の誤差は, Qb の 15 $22 \%$ で あった. VAIVT 間のSFIの経時的変化から VAIVT の介入時期を予測可能か検討した. SFI の減少速度は約 7 割の症 例で経過中に変動し, 種々の減少パターンを認めた. SFI と eSF は, 内シャント血流量の評価に適するが, VAIVT 介入時期の予測に適しない.

\section{A new method for estimating blood flow through arteriovenous fistulas and grafts in patients undergoing hemodialysis}

Yoshinari Wakisaka', Yoshinori Miura

${ }^{1}$ Department of Cardiology, Hoshasen-daiichi Hospital

${ }^{2}$ Department of Urology, Ehime University Graduate School of Medicine

Keywords: blood flow through arteriovenous fistula, restenosis, brachial artery blood flow, vascular access interventional therapy, quantity of hemodialysis blood flow

$\langle$ Abstract〉

The shunt blood flow rate (eSF) of arteriovenous fistulas (AVF) and grafts was estimated using a new method based on the flow volume (FV), the resistance index (RI), and systemic blood pressure. The shunt flow index (SFI), which was created by removing systemic blood pressure parameters from the eSF formula, was compared with the FV and the RI in 79 chronic renal failure patients who underwent more than two rounds of vascular access intervention therapy (VAIVT) to allow hemodialysis (HD) to continue within three years. The sensitivity of the SFI for detecting critical blood flow reductions in AVF was evaluated just before VAIVT. The SFI was more sensitive than the FV and RI at a specificity of $90 \%$, which was measured soon after VAIVT. The eSF was compared with the maximum quantity of blood flow (Qb) during HD in 47 patients, who were selected from the 79 patients because their eSF seemed to be similar to the maximum Qb just before VAIVT. The difference between the eSF and the maximum Qb was $15 \pm 22 \%$ of the maximum Qb. The rates of reduction in the SFI between two VAIVT procedures changed in an irregular manner in about $72 \%$ of the 79 cases. The SFI and eSF are valuable methods for evaluating shunt blood flow through AVF, but are poor at forecasting the optimal dates for subsequent VAIVT procedures.

脇坂 佳成 放射線第一病院循環器科 $\bar{\top}$ 797-0054 愛媛県今治市北日吉町 1-10-50

Yoshinari Wakisaka Tel: 0898-23-3358 Fax: 0898-23-8868

〔受付日：2018 年 10 月 18 日, 受理日：2019 年 7 月 18 日〕 


\section{緒言}

内シャントの血流を現在, 聴診や触診に加えて超音 波検査で評価しているが, これらで内シャントの経皮 経管的血管形成術 (vascular access interventional therapy：VAIVT）の至適な介入時期を予測する方法 は確立していない1 3)。 また超音波検査による抵抗係 数 (resistance index：RI) と上腕動脈血流量（flow volume：FV）を内シャント血流の指標とする報告も あるが4,5)，これらの指標の精度不足が予測を難しくし ている一因と考えた. そこで, 上腕動脈の超音波検査 と血圧測定によって RIやFVよりも正確に内シャント 血流量を推定する方法を考案した，そして，この方法 でVAIVT 後に再狭窄を起こす症例の内シャント血流 量の経時的変化を観察した。

\section{I. 方 法}

\section{1. 内シャント流量の推定方法}

RI と FVに加えて非シャント上肢で測定した血圧を 用いて内シャント血流量を推定する。推定にあたり， 下式の局所的血管抵抗モデルを参考にした6). 局所血管抵抗 $=$

(局所平均動脈圧 - 局所平均静脈圧)/局所血流量

上式において局所的平均静脈圧は動脈圧に比べて小 さいので無視した場合に下式となる.

局所血管抵抗 $=$ 局所平均動脈圧/局所血流量.

動脈硬化の軽い健常者の上腕動脈血流は，拡張末期 にも順行性血流を認めるが，内シャントが閉塞した多 くの症例において拡張末期に上腕動脈の順行性血流を 認めない7)。そして，その閉塞した内シャントを再開 通させると拡張期末期に順行性血流を認めるようにな る.よって, 拡張末期の上腕動脈の血流はすべて内 シャントに流出すると仮定して拡張末期の内シャント 血管系の血管抵抗（SVR）を式(a)で表すと下式(b)と なる。

$\mathrm{SVR} \fallingdotseq \mathrm{Pmini} /(\mathrm{EDV} \cdot \mathrm{S})$

Pmini：上腕動脈の最低血圧, $\mathrm{EDV}$ ：超音波検查 で測定した上腕動脈の心臓拡張末期血流速度,

$\mathrm{S}$ ：EDV を測定している上腕動脈内腔断面積

他方, 収縮期の上腕動脈血流は前腕全体に還流して いるので, 前腕全体の最高血圧時の血管抵抗（AVR） は下式(c)となる.

$\mathrm{AVR}=\mathrm{Pmax} /(\mathrm{PSV} \cdot \mathrm{S})$

$\mathrm{Pmax}$ ：上腕動脈の最高血圧, PSV : 超音波検査て
測定した上腕動脈の心臓収縮期の最高血流速度

SVR と AVR は, 平均血圧時の值と異なるので, そ れらを係数で補正して導き出した推定内シャント血流 量（shunt flow）を考案した.

BPmean $=\mathrm{FV} \cdot \mathrm{AVR} \cdot \alpha \doteqdot$ shunt flow $\cdot \mathrm{SVR} \cdot \beta$

Shunt flow $=\mathrm{FV} \cdot \mathrm{AVR} / \mathrm{SVR} \cdot(\alpha / \beta)+\gamma \cdots \cdots \cdots \cdot(\mathrm{d}$

BPmean：上腕動脈の平均血圧， $\alpha$ : 平均血圧時の 前腕全体の血管抵抗を AVR で除した值, $\beta$ : 平均 血圧時内シャント系の血管抵抗を SVR で除した 值, $\gamma$ :SVR の推定で生じた誤差

式(d)に式(b)と式(c)を代入すると下式になる.

Shunt flow

$=\mathrm{FV} \cdot(\mathrm{Pmax} / \mathrm{Pmini}) \cdot(\mathrm{EDV} / \mathrm{PSV}) \cdot(\alpha / \beta)+\gamma$

$=(\alpha / \beta) \cdot \mathrm{FV} \cdot(\mathrm{Pmax} / \mathrm{Pmini}) \cdot(1-\mathrm{RI})+\gamma \cdots \cdots \cdots(\mathrm{e})$

上式 (e)の妥当性を下記の比較試験で検討する.

\section{1）内シャントの推定血流量の比較試験}

対象は，当院および近隣施設で血液維持透析 (hemodialysis：HD）を受けている83名（男性 59 名，女性 24 名, 年齢 $75.0 \pm 11.2$ 歳（中央值 \pm 標準偏差），糖尿 病患者 31 名, 血液透析期間 $3.9 \pm 4.9$ 年) の夕バコ窩も しくは前腕に作製された自己血管動静脈瘻症例が 82 名, 橈骨動脈に吻合されている人工血管使用動静脈㾞 症例が 1 名である。同一の臨床検査技師が超音波検査 機器（日立製作所製 AVIUS，リニアプローブ：5-18 $\mathrm{MHz}$ )を用いて臥位の患者のシャント肢肘窩で上腕動 脈の血流を測定し, 超音波検査機器に内蔵されるソフ トウェアを用いて RI と FVを算出する．引き続いて動 静脈吻合部付近（人工血管症例は人工血管と静脈の吻 合部付近）で内シャント流出静脈を用手的に圧迫閉鎖 させて再度測定した。この臥床時に非内シャント側の 肘で自動血圧計（TERUMO 電子血圧計 H65）を用い て血圧を測定した。内シャントが流れている状態で測 定した FVを FV (flow) とし，内シャントを圧迫閉鎖 して計測した $\mathrm{FV}$ を $\mathrm{FV}(\mathrm{ob})$ とした. FV (flow) と FV （ob）の差を閉塞法による内シャント血流量（FV (flow-ob)) とする. 可能な限りこの超音波検査を肘 窩の 2 箇所で行い, その平均值を用いる。流速測定に 際してドップラ入射角の補正は, $46.0 \pm 7.4$ 度（最大值 56 度) となっている. 式(e)に $\alpha / \beta=1$ および $\gamma=0$ を 代入した暫定式 (f) を用いて FV と同時に測定した RI と血圧から算出した值を暫定 shunt flowとし, 閉塞時 に測定した数值から算出したものを shunt flow（0 $\mathrm{mL} / \mathrm{min}$ ) とする. 内シャントの血流遮断の判断基準 は, 超音波検査で測定した心臓拡張末期の上腕動脈の 血流速度が $0 \mathrm{~mL} / \mathrm{min}$ 以下もしくは明らかに流出静脈 を指と橈骨の間で触診上圧迫閉塞できている症例であ 
る. 暫定的 shunt flow と FV (flow - ob) の関係および shunt flow $(0 \mathrm{~mL} / \mathrm{min})$ と FV $(\mathrm{ob})$ の関係を調べる. 閉塞法で算出した内シャント血流量を今回考案した推 定方法で説明できるか回帰分析し，その回帰式から $\alpha / \beta$ と $\gamma$ を求め, これらを代入した式(e)を用いて推 定シャント血流量 (estimated shunt flow rate：eSF) を算出することにした.

2) 内シャント血流量の変化が血圧比 (Pmax/Pmini) に及ぼす影響

VAIVT の前後に上腕動脈血流と同時に血圧を測定 した症例が少ないので, eSF から血圧比を除いた FV と（1-RI）の積を shunt flow index（SFI）として， SFIで eSF の代わりに内シャント血流量の低下を評価 できるか検討する．すなわち，内シャント血流量の変 化が血圧比に及ぼす影響を調べる。対象は, VAIVT 当日術前の朝とVAIVT 翌朝の HD 施行直前に血圧を 測定した 43 名（男性 30 名, 女性 13 名, 年齢 $76.7 \pm$ 11.3 歳, 糖尿病患者 25 名, 血液透析期間 $2.9 \pm 3.9$ 年) で, その内の 39 症例はVAIVT 当日にHD を受けず, 4 名はVAIVT 後 2 時間 HD を受けて翌朝も 2 時間 HD を受けているＶVAIVT当日の HD は回路充填量しか 除水していない. 患者を臥位にして自動血圧計で 2 回 計測した血圧の平均值を用いる。

\section{SFI と eSF による臨床経過観察}

対象は，当院および近隣施設で HDを受けていて 2014 年 1 月から 2017 年 12 月までに当院で 2 回以上 VAIVTを受けた患者の中で, 先のVAIVT 直前から 次のVAIVT 直後までシャント肢を超音波検査で経過 観察されている79症例である. 全例が夕バコ窩もしく は前腕に作製された自己血管動静脈㾞症例である。こ の期間中に 3 回以上VAIVTを受けた患者がいたので, 重複しない104回のVAIVT の処置前後のデータを用 いて検討する. 症例数は 32 名（男性 21 名, 女性 11 名, 年歯令 $77.4 \pm 12.5$ 歳, 糖尿病患者 12 名, 血液透析期 間 $2.9 \pm 4.4$ 年）である. 超音波検査方法は，先の試験 と同様である.VAIVTの介入基準は，HDの脱血流量 を $200 \mathrm{~mL} / \mathrm{min}$ とした時に狭窄が原因と思われる脱血 不良を認めた場合もしくは超音波検査で流出静脈の狭 窄部位の内径が $1.5 \mathrm{~mm}$ を下回った場合とした。ただ し, VAIVT 後 90 日以内に血管内径が $1.5 \mathrm{~mm}$ 以下に 再狭窄しても脱血流量が $200 \mathrm{~mL} / \mathrm{min}$ を維持できる症 例は，脱血不良になるまでVAIVTを先送りした，対 象症例において超音波検査による上腕動脈血流の状態 をVAIVTの介入基準から除外している．超音波検査 の検査間隔は，主に 4 週間である. ドプラ入射角度の 補正は, $41.0 \pm 8.6$ 度（最大值 59 度）である。対象症
例のVAIVT の処置間隔は, $99.0 \pm 142.7$ 日（平均值 143.9 日）である.VAIVT 当日から 3 日前に超音波検 査で測定した責任病変の血管内径は, $1.3 \pm 0.3 \mathrm{~mm}$ で ある.この症例群で以下の項目を評価する.

\section{1） SFI の感度の評価}

VAIVT 直前と直後をそれぞれ「処置必要な状態 (positive)」と「処置不要な状態 (negative)」とした 場合に，上記のVAIVT 直前の計測值に対して positive と判定する SFI の感度を RI P FV に対する多重 比較（Bonferroni 法）によって評価する. positive と 判定する閾值は, VAIVT 直後の計測值に対して negative と判定する特異度が 0.9 となる值とする. SFIがこ の閾值で positive と negative に判定する症例数を FV および RI と個別に比較する，検定方法は，McNemar 検定（有意水準 5\%）である.

\section{2) VAIVT 直前の eSF の誤差の評価}

臨床観察対象の中で VAIVT の直前に超音波検査と 同時に血圧を測定した症例が少ないので，全例 VAIVT 前 3 日以内に行われた HD の開始直前に臥位 で測定された血圧比を用いて eSFを算出する。 VAIVT 直前の HD の脱血流量が不明な症例を除外し た中で, 内シャント全体の血流量と HD の脱血流量が 構造的に近いと思われるVAIVT 直前状態 $(\mathrm{n}$ ： 47 , 男 性 16 名, 女性 7 名, 年齢 $75.2 \pm 13.4$ 歳, 糖尿病患者 8 名, 血液透析期間 $2.5 \pm 3.7$ 年)において $\mathrm{eSF}$ VAIVT 直前の HD の脱血流量と比較する。すなわち, VAIVT 当日術前の超音波検查時に狭窄部位の直上の皮膚に印 を入れて撮影された前腕の写真を元に高度狭窄病変が HD の脱血用穿刺部位より動静脈吻合部側にあり，体 表からわかる大きな側枝が高度狭窄病変より吻合部側 にない症例を対象とするＶVAIVT 直近の HD におけ る開始時の脱血流量と終了直前の流量が異なる場合は その平均值を用いる. HD の脱血流量と eSF の差の絶 対值をHDの脱血流量で除したものを誤差率として $\mathrm{eSF}$ を HD の脱血可能血流量の予測值とした場合の誤 差を評価する.

\section{3） SFI から推定した内シャント血流の経時的変化}

経時的に観察される 79 症例は, 先のVAIVT 直後か ら次の VAIVT 直前までの間に全例 3 回以上の超音波 検査を受けている。個々の症例の SFIの減少パターン を主観的に 4 種類（直線状, 階段状, 放物線状, L 字 状）の中から一つ選ぶことにする. この減少パターン で近似式を作成した場合の決定係数 $\left(\mathrm{R}^{2}\right)$ は, 0.85 以上 である。この 4 種類に当てはまらないパターンを分類 不能とする. 


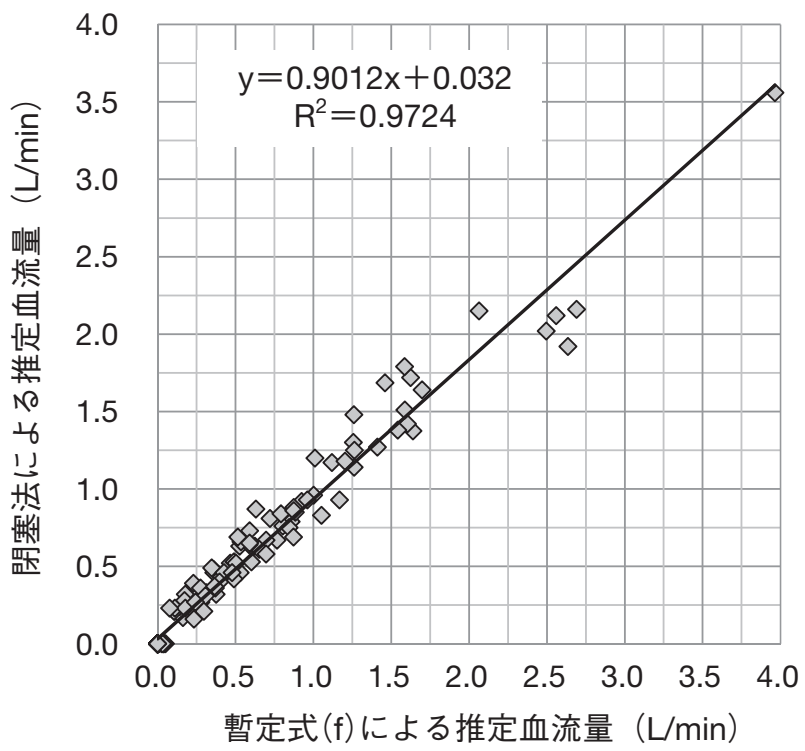

図 1 暫定的な内シャント推定血流量と閉塞法による内 シャント血流量の関係

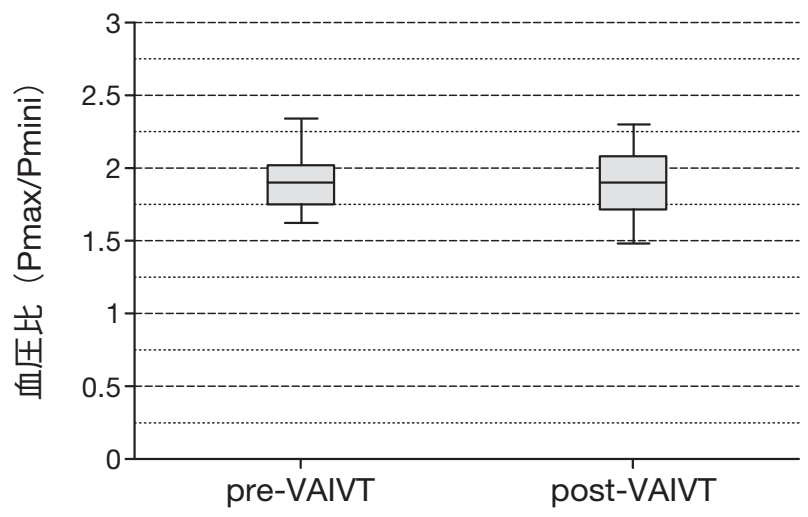

図 2 血圧比の VAIVT 前後の変化

箱は四分位範囲を示し，ひげは $10 \%$ 点と $90 \%$ 点を示す。

\section{II. 結 果}

\section{1. シャント血流量推定方法の評価}

暫定式による非閉塞時の shunt flow は, 中央值が $624.5 \mathrm{~mL} / \mathrm{min}$ で四分位範囲が 359.6-1,143.8 mL/min で あった．暫定式(f)による推定内シャント血流量は，閉 塞法による血流量と正の相関を示し，その $\mathrm{R}^{2} は 0.9724$ であった（図 1)。ゆえに考案した推定方法は適切と考 え，その回帰式である下式 $(\mathrm{g})$ に従って $\mathrm{eSF}$ を算出し た.

$\mathrm{eSF}=0.901 \cdot \mathrm{FV} \cdot(1-\mathrm{RI}) \cdot(\mathrm{Pmax} / \mathrm{Pmini})+32.0 \cdots \cdots \cdots \cdot(\mathrm{g})$

2. 内シャント血流量の増加が血圧比 (Pmax/Pmini) に及ぼす影響

VAIVT 前後の血圧比を全体的にみると，それぞれ $1.90 \pm 0.27$ と $1.90 \pm 0.29$ で近似する（図 2）。個々の症

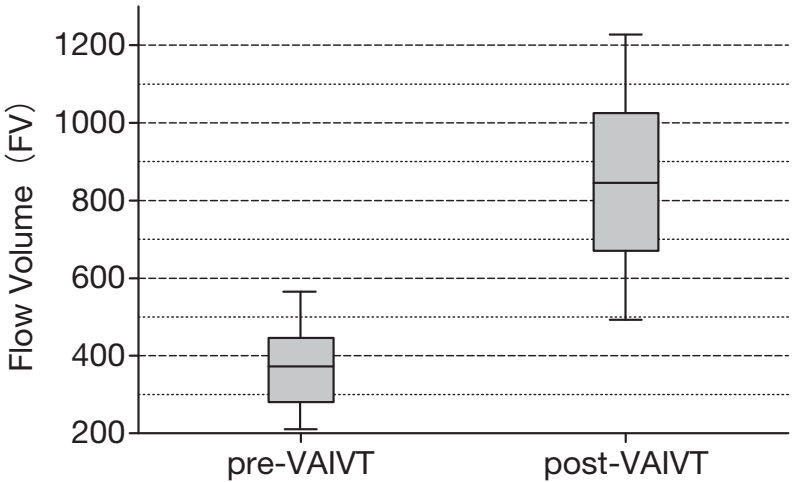

図 3 SFI の VAIVT 前後の変化

箱は四分位範囲を示し，ひげは $10 \%$ 点と $90 \%$ 点を示す。

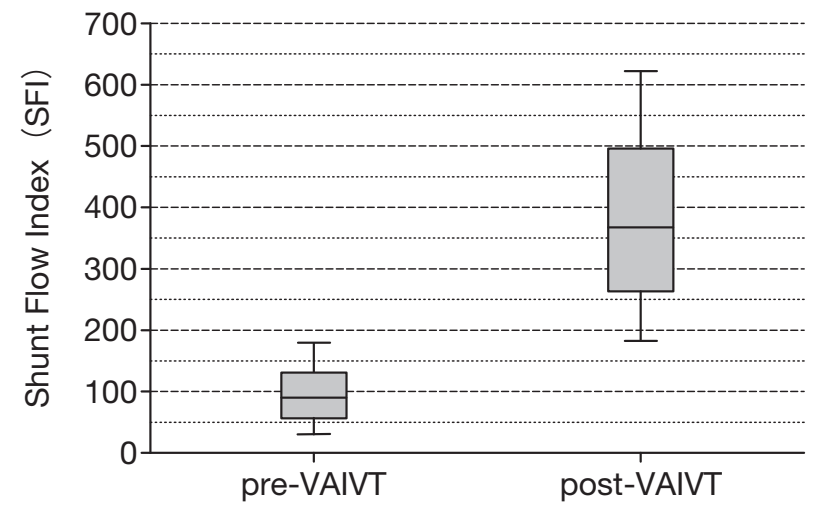

図 4 FV の VAIVT 前後の変化

箱は四分位範囲を示し，ひげは $10 \%$ 点と $90 \%$ 点を示す。

例においてVAIVT 後の血圧比はVAIVT 前の $102.7 \pm$ $1.1 \%$ で少し増加していた. 血圧比は測定ごとに変動し ているが, 全体としては血流改善に伴う血圧比の変化 を認めない. よって, eSF に代わって SFIで同一症例 の内シャント血流量の経時的変化を評価可能と判断し た.

\section{SFIの感度}

SFI と FV の VAIVT 直後の 10\%点 (10percentile) の值は，それぞれVAIVT 直前の $90.6 \%$ 点と $84.0 \%$ 点 に相当する 182.7 と 492.5 であった（図 3，4）．RI は血 流改善によって減少するので, RI の VAIVT 直後の $90 \%$ 点の值は, VAIVT 直前の $25.7 \%$ 点に相当する 0.695 であった（図 5)。すなわち，特異度が 0.90 とな る SFI と FV と RI の感度は，それぞれ 0.906，0.840， 0.743 であった. SFI と FV およびSFI と RI のそれぞ れで比較した positive と negativeの症例数は表 1 のよ うになり，「SFI と FV および SFI と RI の感度が等し い」という帰無仮説を立てた時の $p$ 值は，それぞれ 0.0233 と 0.001 未満となった。 よって, 特異度を 0.9 と した時に SFIは, FV と RIに比べて統計学的有意差を もって感度が高い. 


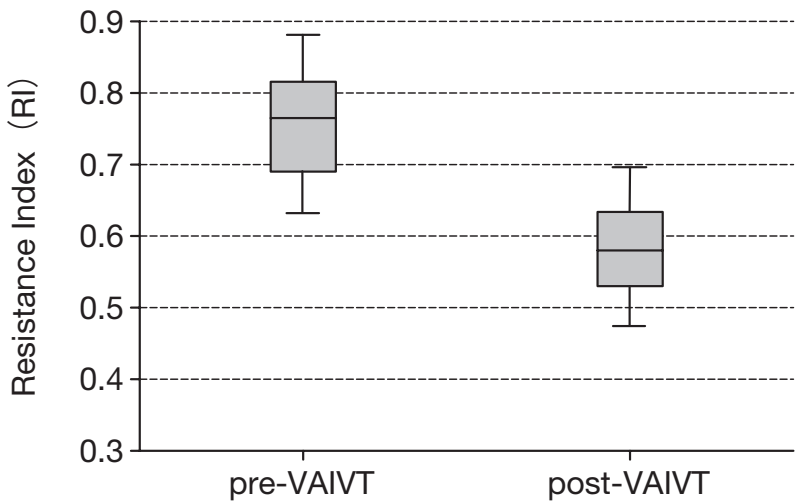

図 5 RI の VAIVT 前後の変化

箱は四分位範囲を示し，ひげは $10 \%$ 点と $90 \%$ 点を示す。

表 $1 \mathrm{FV}$ と RI に対する SFI の感度の個別比較 それぞれの評価方法による陽性 (positive) の症例数 と陰性（negative）の症例数

\begin{tabular}{lcc}
\hline & FV positive & FV negative \\
\hline SFI positive & 87 & 7 \\
SFI negative & 0 & 10 \\
\hline & & \\
\hline & RI positive & RI negative \\
\hline SFI positive & 76 & 18 \\
SFI negative & 1 & 9 \\
\hline
\end{tabular}

\section{VAIVT 直前における eSF の誤差}

評価対象とするVAIVT 直前の HD の脱血流量と eSF は, $200 \pm 25.9 \mathrm{~mL} / \mathrm{min}$ と $197.3 \pm 62.4 \mathrm{~mL} / \mathrm{min}$ で

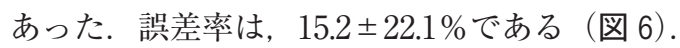

\section{SFI による内シャント血流の経過観察}

SFIの減少速度が一定の症例を 22 例と減少速度が変 動する症例を 57 例認め（表 2)，その実例を図 7 に示 した. SFIの減少速度が変動する症例の内訳は階段状 の低下が 19 例，放物線状の低下が 19 例，L 字状の低 下が 8 例と規則性を認めない症例が 11 例であった．階 段状減少パターンは全例 90 日以上開存しており，90 日以上の処置間隔症例群の中で一番多かった. 90 日以 上の長期開存症例の中で階段状以外の減少パターンの 症例数はパターン間に大差がなく, 減少パターンと処 置間隔にも明らかな傾向はない(図 8).90日以上無処 置で開存しているので狭窄の進行が緩やかと考えられ るのにSFI の減少が不規則な症例を 6 例認めた．無処 置期間が 90 日未満の中では直線状と放物線状の減少 パターンが多い傾向であった.

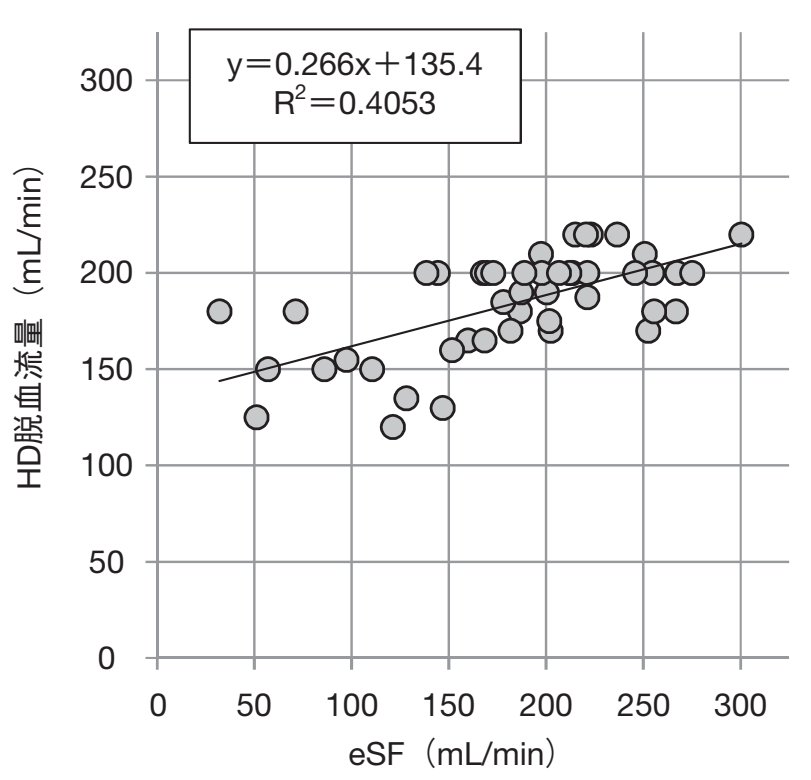

図 6 VAIVT 直前の HD の脱血流量と eSF の関係

\section{III. 考 察}

\section{AVR およびSVRの算出において肘の静脈圧を無視 する影響}

健常者の时の平均静脈圧は, $7 \mathrm{mmHg}^{8)}$ とされる. 今 回血圧比を算出した時に計測した VAIVT 前後の最高 血圧と最低血圧の中央值は 131.0/70.0 mmHg である. シャント肢の肘の静脈圧を健常者の数值で代用して誤 差を計算すると, 肘の静脈圧を除外することによって AVR/SVR は実際より約 5\%小さくなると推定する.

\section{2. 上腕動脈の拡張末期血流量が及ぼす eSF の誤差}

今回閉塞法と比較検討した透析患者 83 名のシャン 卜閉塞時の RI は $1.00 \pm 0.036$ （平均值 0.990）で, その 内の 79 名は, 上腕動脈の拡張末期の順行性血流を認め ていない. よって, 推定 shunt flow と閉塞法による推 定血流量がよい相関を示すが，拡張末期血流が多い透 析患者の eSF は, 誤差が大きい可能性がある.

3. 高度狭窄病変が HD の脱血部位より流出側にある 症例や動静脈吻合部付近に大きな側枝がある症例 の VAIVT 直前の HD の脱血流量と eSF の関係

79 症例の 104 回の VAIVT においてVAIVT 直前の HD の脱血流量が判明し, 高度狭窄病変が脱血部位よ り流出側にある症例や動静脈吻合部付近に大きな側枝 を有する術前状態を 26 回認める。この症例群の VAIVT 直前の eSF は, HD の脱血流量と近似してい ない. eSF は, シャント吻合部から静脈に流出する総 血流量の推定であるので, 内シャントの形態によって eSF から推定する HD の脱血可能血流量の誤差は異な る. 


\begin{tabular}{lccccc}
\hline & 直線状 & \multicolumn{4}{c}{ 非直線状 } \\
& & 階段状 & 放物線状 & L 字状 & 分類不能 \\
\hline 無処置間隔が90 日以上の症例 & 10 & 19 & 8 & 6 & 7 \\
無処置間隔が90 日未満の症例 & 12 & 0 & 11 & 2 & 4 \\
\hline 処置間隔によらない症例 & 22 & 19 & 19 & 8 & 11 \\
\hline
\end{tabular}

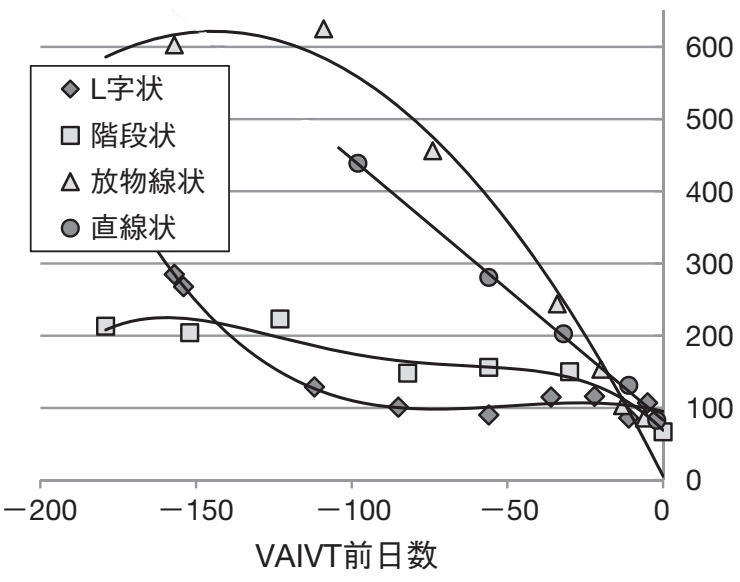

図 74 種類の変動する SFI 減少パターンの実例

\section{SFI および eSF の有用性}

SFI は，RI と FV を個別に評価することと比べて両 者の測定誤差を相乗的に内包する短所を有する可能性 がある.しかし, 今回の結果は FV と RI の片方の数值 だけがVAIVT の介入を示唆するような上腕動脈血流 の評価が難しい症例をSFIによって一元的に評価でき ることを示している，超音波検査測定結果は，施行者 間のバリアンスが危惧される ${ }^{9)}$ が, eSF は個々の検查 施行者が閉塞法と比較試験を行って誤差を評価できる ことも FVや RI より優れていると考える.

閉塞法は簡便に測定できることが多いが，吻合部付 近で完全にシャント流出静脈を閉塞できない症例や前 腕の圧迫による橈骨動脈末梢血流の阻害が疑われる症 例を経験したので, eSF は閉塞法に比べて手技に影響 されにくい利点を有すると考える.

内シャント流出静脈の狭窄部位, HD の脱血部位扮 よび側枝の位置関係から適した症例を選ぶと, eSFを $\mathrm{HD}$ の脱血可能血流量の指標として利用できる，ただ し, VAIVT 直前の $\mathrm{eSF}$ は脱血流量に対する $\mathrm{R}^{2} か ゙$ 低 かったので, 脱血流量に大きく影響するその他の因子 が存在する.

\section{5. 今回の VAIVT の適応基準の妥当性}

対象症例の VAIVT 直前の FV が $372.0 \pm 137.2 \mathrm{~mL} /$ min なので, 一般的基準と比較して本研究の VAIVT の介入時期は妥当と考元る ${ }^{10)}$.

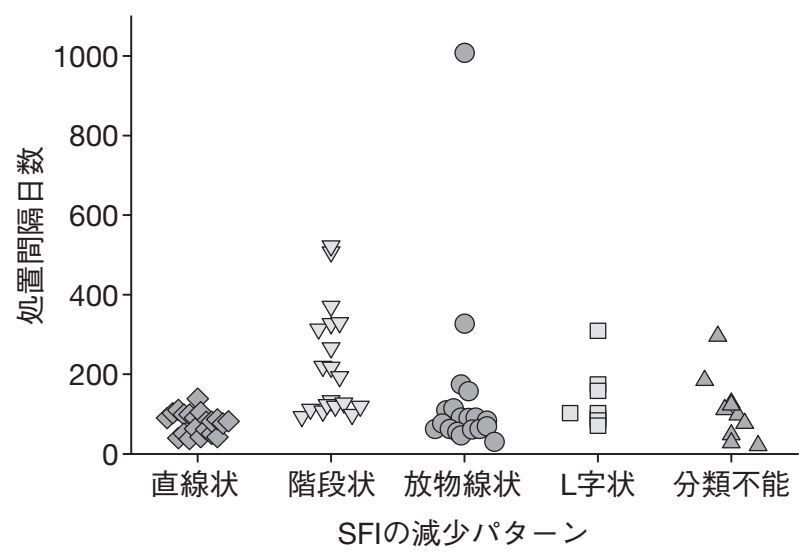

図 8 各々のSFIの減少パターンと処置間隔日数の関係

\section{6. eSF の補正方法}

比較試験における $\mathrm{FV}(\mathrm{ob})$ が $140 \pm 103 \mathrm{~mL} / \mathrm{min}$ だっ たことは健常者と比べると少ないが妥当と思われ る11,12). しかしながら, FV (ob)が 30〜50 mL/min で 指のチアノーゼを認めない症例を少なからず認めるの で FV (ob) は実血流量よりも少ない可能性がある．内 シャントの血流が少ない症例では $\mathrm{FV}(\mathrm{ob})$ の誤差の影 響が大きくなるので，閉塞法の誤差率が大きい可能性 がある.

\section{7. 内シャント血流の経過}

多くの症例で観察期間中にSFI の減少速度は変動し ている. SFI の減少パターンは症例によって異なって いる. SFI の減少速度が一定でない症例を 4 種類に分 類しているが，現状ではこれらの分類に影響する要因 を見出せない. 図 7 の L 字状減少パターン症例におい て SFIが 100 付近の日まで減少パターンが直線状減少 と判別できないので, 内シャントの血流量の過去の経 過だけで将来の血流減少を予測することが困難と思わ れる. 今後 VAIVT 後の血流減少の解析を進めて次回 の超音波検查や VAIVT 介入の至適時期を予測する方 法を検討したい。

全体の約 14\%の症例で狭窄の進行と連動せずにSFI が不規則に変動していた。これは，血圧比の変動を含 む推定方法の誤差も影響するが，それ以外の要因も疑 われる，循環動態が近似する状態で検査するのが好ま 
しいので，超音波検査を HD 開始直前もしくは直後に 統一すべきと考える. 当院透析室でポータブル超音波 検査器を用いてエコーガイド下に留置針を穿刺する手 法が導入されているので，HD 開始時直前の eSF の測 定を検討したい。

\section{結＼cjkstart語}

1. 今回考案した内シャント血流量の指標である SFI は, 既存の評価方法よりも血流低下に対する感度 が高い. SFI と血圧比の積である eSF は，内シャ ント血流量の評価に有用であると考える.

2. 内シャント血流量の経過観察を行った結果, 再狭 窄による血流低下の過程が個々の症例で大きく異 なると考える.よって, 内シャント血流量の推定だ けではVAIVT介入時期の予測は困難である。しか し, 内シャント血流量の経過観察は, 再狭窄の進行 を把握するのに有用と考える.

本研究は愛媛大学医学部附属病院の臨床研究倫理審査委 員会にて研究実施の承認を受けている（受付番号： 1809025).

本論文内容は, 第 22 回日本アクセス研究会学術集会・総 会で発表した。

COI開示 : 筆者に開示すべきCOI関係にある企業はない.

統計処理とグラフ作成 : 統計処理とグラフ作成は, Excel 2007 と KyPlot 5.0 を用いている.

謝辞：論文作成と倫理委員会申請にあたり丹司望氏の協 力を得ている.
文献

1）尾上篤志, 大野卓志, 高橋計行, 吉本忍, 今田聡雄. 超音波検查における前腕内シャント狭窄の検出とシャ ント機能不全の予測. 大阪透析研会誌 2002；20：65-8.

2) 山本裕也, 日野紘子, 小林大樹, 中山祐治, 中村順一. 超音波パルスドップラ法による自己血管内シャント機 能評価の有用性. 超音波検査技術 2011；36：219-23.

3）春口洋昭. シャント機能とは? 大平整爾監, 春口洋 昭編. バスキュラーアクセス診断学. 東京 : 中外医学 社, 2012; 32-44.

4）柳沢良三，峰正英，雨宮裕，矢崎恒忠，菊池史．超音 波 Bモードパルスドップラー複合法によるシャント不 全の早期診断. 透析会誌 2003；36：1255-8.

5）日本 IVR 学会 VAIVT ワーキンググループ. 血液透析 用バスキュラーアクセスのインターベンションによる 修復 (VAIVT: Vascular Access Intervention Therapy）の基本的技術に関するガイドライン第 1 版. $2016 ; 5-6$.

6) James J. Smith, John P. Kampine. Circulatory Physiology Second Edition. 東京 : 医学書院, 1989；18-34.

7）小林大樹, 山本裕也, 中山裕治, 平中俊行. 超音波パ ルスドップラ法における血流波形とシャント狭窄との 関連性について，腎と透析別冊アクセス 2007；63： 189-92.

8）村田和彦, 細田瑳一. 循環器病学第 2 版. 東京：医学 書院, $1987 ; 423$.

9）日本透析医学会. 慢性血液透析用バスキュラーアクセ スの作製および修復に関するガイドライン，透析会誌 2011；44：855-937.

10）山本裕也．血管超音波とバスキュラーアクセス．春口 洋昭編．バスキュラーアクセス超音波テキスト．東 京: 医歯薬出版, 2011；53-62.

11）James J. Smith, John P. Kampine. 特殊部位への循環 (小林明芳訳). 村松準監訳. 循環の生理第 2 版. 東京： 医学書院，1989；196-239.

12）小川智也. 内シャントの血行動態. 大平整爾監，春口 洋昭編. バスキュラーアクセス診断学. 東京: 中外医 学社, 2012; 27-31. 